\title{
Final submitted version of
}

Vuaridel, M., Cherubini, P., Mettra, F., Vennemann, T., and Lane, S.N., 2019. Climatedriven change in the water sourced by trees in a de-glaciating proglacial forefield, Torres del Paine, Chile. Ecohydrology, 12, e2133

https://onlinelibrary.wiley.com/doi/full/10.1002/eco.2133

\section{Climate-driven change in the water sourced by trees in a de-glaciating proglacial} fore-field, Torres del Paine, Chile

Running title : Climate change influences on water used by trees in a proglacial margin

Vuaridel, M. ${ }^{(1)}$, Cherubini, P. ${ }^{(2)}$, Mettra, F. ${ }^{(1)}$, Vennemann, T. ${ }^{(1)}$ and Lane, S.N. ${ }^{(1)}$

1. Institute of Earth Surface Dynamics, University of Lausanne, $\mathrm{CH}-1015$ LAUSANNE, Switzerland

2. Swiss Federal Institute for Forest, Snow and Landscape Research (WSL), CH8903 BIRMENSDORF, Switzerland

Contact author: Stuart Lane, Institute of Earth Surface Dynamics, University of Lausanne, CH-1015 LAUSANNE, Switzerland. Email address: stuart.lane@unil.ch

\section{Abstract}

The colonisation of proglacial margins by vegetation following glacier recession is a slow process, not least because glacially produced sediments are commonly well-drained. Following from human-induced climate change, warming could increase both growth rates and water availability because of glacier melting, so compensating for situations where climate change reduces precipitation. Offsetting is likely a function of location, which will control access to meltwater and groundwater, themselves spatially variable. For the Olguin glacier (Torres del Paine, Chile) we test the hypothesis that as climate has warmed and precipitation has fallen, tree-growth rate response is dependent upon the access of trees to glacial meltwater. Cores were taken from trees in three revegetating zones: (Z1) proglacial stream proximal; (Z3) proglacial stream distal; and (Z2) intermediate between $\mathrm{Z} 1$ and $Z 3$. For trees within each zone, we measured annual tree-ring widths and $\delta^{2} \mathrm{H}$ values. $Z 1$ growth rates were strongly correlated with temperature, $Z 3$ with precipitation and $Z 2$ showed a shift from precipitation-correlation (i.e. following $Z 3$ ) to temperaturecorrelation (i.e. following Z1) through time. $\delta^{2} \mathrm{H}$ values were lowest at $\mathrm{Z1}$, reflecting water 
of glacial origin; highest at Z3 reflecting meteoric water supply; and shifted through time at Z2 from meteoric to glacial. Increased water supply associated with temperature-driven glacier recession may compensate for decreasing water supply from precipitation to influence tree growth. This compensation is likely related to the spatial organisation of the subsurface flux of glacial melt and leads to different revegetation processes to those envisaged in the classical chronosequence model of vegetation following glacier recession.

\section{Key words}

recolonisation, vegetation, proglacial, glacier recession, dendrochronology, hydrogen isotopes, groundwater

\section{Introduction}

A worldwide rise in atmospheric temperatures has been recorded during the last century (Meehl et al. 2005). Mean temperatures in the European Alps increased more than twice as much as the global average over the second part of the $20^{\text {th }}$ century (Rebetez and Reinhard 2008; Brunetti et al. 2009). This is similar for mountain regions in the southern hemisphere (Perez et al., 2018). In response to this warming, the global water cycle has changed fundamentally, including a decrease in annual rainfall in certain regions (Jansson et al. 2003). Some parts of the world now regularly undergo droughts that were extremely rare 100 years ago (Griffin and Anchukaitis, 2014). A combination of warming-driven ablation and reduced accumulation has led to the shrinkage of global ice cover (Perez et al., 2018; Haeberli et al. 2007), with a rate of loss of $259 \pm 28 \mathrm{Gt} \mathrm{y}^{-1}$ of ice between 2003 and 2009 (Gardner et al. 2013). In most Alpine regions of the world, glaciers are undergoing rapid recession (Dyurgerov and Meier 2000; Perez et al., 2018).

During glacier retreat, the proglacial environment is entirely reshaped, leading to the progressive evolution of its hydrology, geomorphology and related ecosystems (Barnett et al. 2005; Casassa et al. 2007; Miller and Lane, 2019). Studies of ecological succession in glacier forelands began at the end of the 19th century (Cooper 1923; Coaz 1887). These studies argued that ecosystem development was a function of time since deglaciation, which was theorised via a space-for-time substitution (Matthews, 1992) as a chronosequence. Matthews (1992) proposed a more developed conceptual model where ecological succession was not simply interpreted as a function of time but also: (1) abiotic processes such as soil grain size, micro-relief, micro-climate, hydrology, slope, geomorphic stability (Burga et al. 2010; Rydgren et al. 2014; Wietrzyk et al. 2016; Garibotti et al., 2011); and (2) biotic processes including species interaction and competition (Schumann et al., 2016). Initially, the spatial heterogeneity in abiotic processes is thought to be dominant, but as the terrain becomes more stable and ecosystem succession advances, biotic factors are thought to become more influential (Matthews 1992). Most recently, this has been conceptualised as a biogeomorphic sucession (Miller and Lane, 2019). 
The rates of climate change and glacier recession since the 1980s have been exceptional as compared with the period between the Little Ice Age of the 1800s and the 1980s (e.g. Pelliciotti et al. 2005; Lynch et al. 2016). This is leading to a rapid increase in the rate of production of deglaciated terrain, rendering abiotic heterogeneity more important because the spatial extent of deglaciated terrain produced over relatively short periods is very high (Cannone, 2008; Miller and Lane, 2019). One of the primary influences upon ecosystem succession in deglaciated terrain is access to water (Caccianiga and Andreis 2011; Wietrzyk et al. 2016). Plants growing on sediment capable of retaining moisture (e.g. clay/silt) or close to zones where surface water can be maintained by impermeable layers (e.g. biofilm-related; Miller and Lane, 2019) have significantly higher growth rates (Burga et al. 2010). Water in proglacial margins can come from a number of different sources (rainfall, snow melt, hillslopes, shallow groundwater, deep groundwater, proglacial streams) and access to these sources clearly influences plant growth patterns (Brown et al. 2007; Miller and Lane, 2019). Deglaciation in some regions of the world has been attributed to systematic changes in precipitation patterns. Deglaciation also means a net increase in stream runoff as compared to that available from precipitation (directly, or through snow melt) alone. Thus, it is possible that the water sources available to vegetation in proglacial margins are changing. Whilst rainfall reductions might impact all proglacial margin zones, some zones may witness increased shallow groundwater access due to greater glacial meltwater-driven recharge (Leonelli et al., 2014, 2017). Proglacial streamwater drains laterally into stream proximal zones in proglacial forefields during the day time discharge rise (Cooper et al., 2002; Magnusson et al., 2014; Deuerling et al., 2018), and then either returns to the stream or drains vertically or longitudinally (where possible) into till. In turn, it might be hypothesised that changing water availability is reflected in tree growth, provided that trees can access water derived from groundwater or the proglacial stream. Although the hydrology of groundwater flux in Alpine catchments is relatively poorly known, it is likely that abiotic controls relating to water availability explain different spatial patterns of tree growth and these cause vegetation response to diverge from that associated with the traditional chronosequence model. Hence, we test two hypotheses in this paper.

(1) trees that are close to the proglacial stream benefit from a reduction in the temperature limitation of growth rates due to climate warming, because they are able to secure better access to greater rates of glacier melt induced runoff;

(2) trees that are more distal switch from temperature limitation to moisture limitation, due to decreasing precipitation.

These hypotheses were tested for the Olguin glacier in the Torres del Paine National Park, Chile. Tree cores were extracted from: (1) a proglacial stream proximal zone (Z1); (2) a proglacial stream distal zone (Z3); and (3) an intermediate zone (Z2). They were used to determine (a) annual growth rates; and (b), using hydrogen isotope based $\left(\delta^{2} \mathrm{H}\right)$ analysis, the dominant source of water associated with each annual growth ring. These were combined with a 30-year climate time-series (temperature and precipitation) downscaled to the study site to explore changing relationships between growth rates, climate parameters and water sources. 


\section{Materials and methods}

All data used in this study are available in the Supplementary Materials section.

\section{Study area}

The study area is located in the Torres del Paine National Park at the South-eastern side of the southern Patagonia ice field in Chile (Figure 1). It has a relatively low mean annual precipitation (730 $\mathrm{mm}$ per year for the Torres del Paine area, Tognetti, et al., 2014) as compared with the western Andes but is relatively highly glaciated. It is considered as having a Norwegian climate according to the De Martonne classification and Cfc according to the Köppen classification. This study focuses on the Olguin glacier and its forefields (Figure 1), including the Olguin torrent that flows to the Grey Lake through a forest composed mostly of bushes and Nothofagus antarctica (G. Forster) Oerster trees. The site is located in the Patagonian deciduous transition zone between the evergreen forests in the west and Patagonian steppes in the east. Unlike most of the larger glaciers in this region, the Olguin glacier is representative of smaller alpine glaciers in this region and it was selected as it has been unimpacted by human activities other than human induced climate change. Its accumulation zone culminates at $1450 \mathrm{~m}$. The glacier margin is currently at about $800 \mathrm{~m}$ altitude. Although the torrent is mostly fed by Olguin glacier melt water, the catchment includes other small alpine glaciers that also contribute to its flow. On the basis of recently deglaciated terrain, the glacier bed is likely to be predominantly till with some bedrock outcrops.

Average air temperatures in Southern Chile increased by between 0.4 and $1.4{ }^{\circ} \mathrm{C}$ during the $20^{\text {th }}$ century (Rosenblüth et al. 1997). Rasmussen et al. (2007) reported a $0.5^{\circ} \mathrm{C}$ rise at $850 \mathrm{hPa}$ over the Patagonia icefields during 1960-99, both in winter and in summer, from NCEP-NCAR reanalysis. This warming, combined with a local decrease in precipitation has caused an accelerated loss of Patagonian ice cover (Aniya 1988). This phenomenon has intensified during the past three decades, during which glaciers have retreated faster than any time in the last 350 years (Glasser et al., 2011).

\section{Study zones}

Three study zones were selected in the Olguin glacier's proglacial margin, but beyond the Little Ice Age maximum glacier extent. We chose to do this to avoid comparing zones with very different relative lengths of time since deglaciation. The first zone (Z1) was chosen to include stream-marginal trees that would clearly, through their rooting systems, be able to access glacially-derived melt water ( $x$ in yellow on Figure 2 ). Their roots were very close to, or directly in, the glacial torrent or outwash plain. In the second zone (Z2) trees were chosen that might have some access to glacier melt, notably through deeper groundwater flows sustained by such melt (o in light blue on Figure 2). The third zone (Z3) included trees that were unlikely to be fed by glacial melt water $(+$ in red on Figure 2$)$. This statement is based on topographic criteria, distance from the glacier and soil type. Most of them are located on well-drained elevated morainic terrain, where glacial melt water 
does not accumulate (Jenny 1994). In all cases, the soils were shallow, estimated at less than 0.4 to $0.5 \mathrm{~m}$ in depth, implying also that rooting systems were shallow.

\section{Tree selection and sampling of cores}

Within each zone, 15 trees with similar girth dimensions were sampled between December 2016 and January 2017. In order to avoid bias related to species-specific differences in growth rates and hydrogen fractionation between different tree species, all the cores were extracted from $N$. antarctica trees. Considered to be the southernmost species on Earth, it represents the vast majority of trees in the area. Two cores $(5 \mathrm{~mm}$ diameter) were extracted from each tree at about $1.3 \mathrm{~m}$ above ground, as suggested for standard dendrochronological analyses (Speer 2012).

\section{Tree-ring growth}

The cores were cut transversally using a microtome with the aim of enhancing tree-ring visibility without compromising the annual separation of tree-ring cellulose (McCarroll and Loader, 2004). Ring-width measurements were made to the nearest $0.01 \mathrm{~mm}$ on the cores, using TSAP-measurement equipment and software package (Frank Rinn, Heidelberg, Germany). The raw ring-widths of the single curves of each dated tree were plotted, cross-dated visually and then cross-dated statistically by; a) the Gleichläufigkeit (there is no English equivalent to this term), a measure of the year-to-year agreement between the interval trends of two tree ring chronologies based upon the sign of agreement, usually expressed as a percentage of cases of agreement; and b) Student's $t$-test, to determine the degree of correlation between the curves. We did not adopt standardization techniques, commonly used to remove the low-frequency variability attributable to stand dynamics and tree age, by dividing the measurements by a standardising smoothing function and their conversion to a time series of ring-width indices, because such techniques remove other low-frequency signals, such as evidence of climate change (Briffa et al., 1996, Sullivan et al. 2016). Once we had completed this process, we set 1985-86 as the start year for the study, reflecting the point from which we felt the tree rings were reliably dated and also the climate data that we had access to (see below).

\section{Determination of water source using isotope analyses}

In this paper, we focus upon the record of hydrogen isotope composition recorded in cellulose. It has been shown that the ratio of heavy to light hydrogen, oxygen and carbon isotopes in plant organic matter are mainly driven by the partial pressure of water (for $\mathrm{C}$ ) and the isotopic composition of water at the leaf level of the plant (for $\mathrm{H}$ and $\mathrm{O}$ ) (Craig 1961; Dansgaard 1964). However, isotopic composition of cellulose is also influenced by the water source available to tree roots. Researchers have not yet defined whether the $\mathrm{H}$, $\mathrm{O}$ or $\mathrm{C}$ composition is the most appropriate isotope system to trace the origin of water in cellulose. Most studies involving dendrochronology and wood isotope compositions use $\delta^{18} \mathrm{O}$ combined with $\delta^{13} \mathrm{C}$ values with the former tracing the water cycle and the latter 
tracing the cycle of $\mathrm{CO}_{2}$ (e.g. Leonelli et al. 2014). The exact choice may not make much difference though (e.g., McCarroll and Loader 2004). Even though $\mathrm{H}, \mathrm{O}$ and $\mathrm{C}$ isotopes are processed and assimilated differently by organic matter, the processes are relatively similar, in particular for $\mathrm{H}$ and $\mathrm{O}$, even in different ecological systems and plants. Of the three isotopic systems, the hydrogen isotope composition of cellulose is most directly related to that of water simply because this is the ultimate source of hydrogen in cellulose. In contrast, oxygen isotopes can be derived both from water and $\mathrm{CO}_{2}$, hence there are more influences on $\mathrm{O}$ isotope fractionation than upon $\mathrm{H}$. Studies that have considered the $\mathrm{H}$-isotopic composition of water used by trees in addition to the isotopic composition of their cellulose have shown that, in contrast to oxygen isotope compositions, the cellulose is generally somewhat more depleted in ${ }^{2} \mathrm{H}$ compared to the water used for its synthesis (e.g., McCarroll andLoader 2004; Leonelli et al. 2014). For any one type of plant, this offset is considered to be constant though. Hence we focus on measurements of the hydrogen isotope compositions ( $\delta^{2} \mathrm{H}$ values) in plant cellulose. In a glaciated catchment, the $\mathrm{H}$ isotope compositions may be used to determine water sources because of altitudinal and temperature dependence of $\delta^{2} \mathrm{H}$ values in precipitation. Glaciers generally contain water that is depleted in the heavy isotopes of water compared to the average annual precipitation at any one site because glaciers are formed predominantly from winter precipitation (e.g., Criss 1999). Thus, meltwater at a glacier tongue should be more depleted in heavy isotopes compared to average annual precipitation at the same elevation (Siegenthaler and Oeschger 1980). Glacial streams should then become gradually enriched in heavy isotopes with distance downstream under the influence of non-glacial tributary streams that are commonly sourced from groundwaters fed by the annual precipitation (Leuenberger 1998). We should therefore be able to distinguish between trees mainly fed by glacier water compared to those fed by the average annual precipitation by analysing the cellulose $\delta^{2} \mathrm{H}$ values (e.g., McCarroll and Loader 2004; Leonelli et al. 2014, 2017). In this study the $\delta^{2} \mathrm{H}$ values for annual growth rings were used to examine the relationships between annual growth rates and predominant water sources.

Within each zone, four trees were selected for isotopic analyses based on three criteria. First, the Gleichläufigkeit value was used to choose the trees with the highest synchronicity with the mean growth rate of each zone. Second, tree-ring visibility was considered because even when rings are clear enough to measure them, they may be difficult to separate precisely with a surgical blade for eventual sampling for isotope analysis. Third, wood quality was considered, because some series contained several darker or softer altered rings (Shortle 2012). Even if their quality was good enough for counting and measuring, it cannot be excluded that their isotopic composition has not been altered due to some local event or disease. With four trees per zone, three zones and a 30 -year data series (1985 to 2015 ), this meant the analysis of 360 rings.

Samples were dried for a minimum of $48 \mathrm{~h}$ at $40^{\circ} \mathrm{C}$. Each ring was then separated and manually milled with a mortar, weighed (between 150 and $300 \mu \mathrm{g}$ ) and wrapped in silver capsules. Samples were run in sequences together with water standards and NBS22 (oil) reference material for normalization of the $\delta^{2} \mathrm{H}$ values to the VSMOW scale (Haiping et al. 
2014). In addition, drift corrections were made using an in-house kaolinite standard. Samples were analysed on a TC/EA (High-Temperature Elemental Analyser) linked to a Finnigan MAT 253 mass spectrometer at the University of Lausanne.

263

This approach relies upon the validity of the isotope ratio theory for the water cycle (Leuenberger, 1998), and its validity was assessed separately in the studied area. Twelve water samples were collected and analysed to measure their $\delta^{2} \mathrm{H}$ value in order to verify the consistency between the two and thus validate the adequacy of the use of $\delta^{2} \mathrm{H}$ values. The water samples were from (i) rain (on different dates and at different elevations); (ii) glacial melt (at different elevations); (iii) a glacial lake; and (iv) groundwater in proglacial stream proximal zones (on different dates). The latter were collected at a natural spring. Each sample was analysed with a Picarro 2140i Cavity-Ring-Down laser spectrometer according to the method described in Halder et al. (2013).

The precision was estimated by reproducibility of standards and samples run in duplicate or triplicate and are better than 1.0 permil for $\mathrm{H}$-isotope compositions expressed as $\delta$ values relative to $\mathrm{VSMOW}$ for the cellulose and better than 0.5 permil for measurements of water. According to theory, each water source could have distinct $\delta^{2} \mathrm{H}$ values. Glacier ice should be the most depleted in the heavy isotopes for hydrogen. Rainwater and stream water have higher $\delta^{2} \mathrm{H}$ values at lower elevations (e.g., Clark and Fritz 1997, Criss, 1999).

\section{Climate data}

No climatic data specific to Ogluin glacier are available, nor is information on its melting rate. However, as this study is interested in the relationship between general climatic tendencies and tree growth rates, estimates from the Meteoblue weather+ model, $30 \mathrm{~km}$ east of the study site $(-50.9826,-72.4988)$ were used. This site, and the glacier, are both located east of the Andean Cordilleras, the strongest influence on spatial variability in local climate, and hence data from this site is considered to be appropriate. Data are available from 1985. Details of the data used are available at (https://www.meteoblue.com/en/historyplus). Mean values for temperature and precipitation were calculated for the growing period (October to March) and are available in Supplementary Material 1 along with the standard deviations. Other factors can influence growth and water access such as snow cover and solar radiation (Raffl et al., 2006). They were deliberately ignored because of insufficient reliable data.

\section{Results}

\section{Tree growth rates and climate change}

Figure 3 shows zonal growth rates through time (raw data are provided in the Supplementary Material section). The concordance between Z1 and Z3 was low: the Gleichläufigkeit was $53 \%$, and the two curves were not similar $(p>0.05)$. The correlation was also low ( $r=-0.16)$. The same conclusion was made for the concordance between $\mathrm{Z1}$ and Z2 (Gleichläufigkeit $=49 \%, p>0.05, r=0.02$ ). There was some concordance between 
Z2 and Z3 (Gleichläufigkeit $=64 \%, p<0.05$ and, $r=0.54$ ). There was a significant negative correlation between growth rate and time for $Z 3(r=-0.64, p<0.05)$, a significant negative correlation $(r=-0.42, p<0.05)$ for $Z 2$, but a significant positive correlation for $Z 1 \quad(r=0.32$, $\mathrm{p}<0.05)$.

Over the study period, there was a significant negative correlation between precipitation and time $(r=-0.47, p<0.05)$ and a positive correlation between temperature and time but this was not significant $(r=0.18, p>0.05)$. Correlations between growth rates and climate parameters (see also Figure 4) suggest the response of trees in the three zones was different. For Z1, growth rates were significantly correlated with temperature $(r=0.62$, $p<0.05)$ but not precipitation $(r=-0.20, p>0.05)$. For $Z 2$, growth rates were significantly correlated with temperature $(r=0.30, p<0.05)$ as well as with precipitation $(r=0.48, p<0.05)$. For Z3, growth rates were not significantly correlated with temperature $(r=-0.20, p>0.05)$ but were significantly correlated with precipitation $(r=0.67, p<0.05)$.

These gross correlations hide variability in correlation over different scales and through time. To illustrate this, Figure 5 shows windowed correlations between growth rates and temperature and precipitation for each zone. As expected, Z1 growth rates have strong correlations with temperature which is most likely due to the constant and sufficient supply of melt water in that zone. This correlation is more significant from 2005 onwards. The correlations between $\mathrm{Z} 1$ growth rates and precipitation are weaker and the sign of the correlation depends on the year and window size. In other words, it displays no definite pattern, with some strong positive and negative correlations. For instance, 2001-2006 has a positive correlation over shorter time-scales. During this period, cooler years were also drier, and this may have given rise to some precipitation limitation due to less ice melt. Either side of this period, correlations over shorter timescales are generally negative, and reflect that wetter years were also cooler with lower growth rates, and that temperature limitation was important.

Growth rates for Z3, the distal zone, are strongly correlated with precipitation from the mid-1990s, potentially because of an absence of other water sources, such as glacial meltwater, which makes tree growth dependent on precipitation. The strengthening of the correlation over time is very likely due to the rise in air temperature, which has become sufficiently high and constant over the years to no longer be a limiting factor. The effect of precipitation is thus increased. The correlation between $\mathrm{Z3}$ growth rates and temperature is mainly negative and mostly insignificant.

Z2 growth rates are mainly positively correlated with precipitation, but this correlation is getting weaker over time. Depending on the window size, the correlations even become negative over the last decade. The Z2 dependence on precipitation is therefore decreasing, which leads to the suggestion that rainfall is becoming less important. The most likely explanation is the increase in meltwater supply via groundwater due to the accelerated glacier retreat, which has the impact of decreasing the influence of precipitation. The correlations between $\mathrm{Z} 2$ growth rates and temperature display a more obvious shift. Before 2003, this correlation is weak. But the correlation gets significantly 
stronger over a short period of time. Depending on the window size, this rapid change occurs between 2003 and 2008. The most likely explanation is a shift to temperature limitation due to an increase in meltwater supply associated with accelerated glacier recession, which has the impact of decreasing the influence of precipitation in the intermediate zone making temperature the controlling factor.

\section{Isotopic composition of water samples}

Given that the isotopic composition of different water sources is indeed different (Table 1 ), this confirms the applicability of hydrogen isotope water cycle analysis in the studied area. Rainwater is more depleted in ${ }^{2} \mathrm{H}$ at higher elevations or at lower mean ambient air temperatures during condensation as a result of the so-called "rain-out" effect (e.g., Clark and Fritz 1997). Such differences are not unexpected (e.g., Otte et al., 2017) and the difference between the two samples taken at $700 \mathrm{~m}$ but on different dates can be explained by different origins of the air mass and/or different ambient meteorological conditions. The glacier ice-derived water has lower $\delta^{2} \mathrm{H}$ values as it is depleted in ${ }^{2} \mathrm{H}$ compared to the average annual precipitation and this water finds itself as a dominant contribution to the meltwater stream. For the sampling dates it is noted that the $\delta^{2} \mathrm{H}$ values of the stream waters also do not change very much with distance downstream, which suggests that non-glacial sources of water (surface run-off of recent precipitation) do not contribute significant amounts of water to the stream water. The low $\delta^{2} \mathrm{H}$ values in tree rings are also likely to indicate an important use of glacial meltwater by trees. The groundwater typically has an isotopic composition that is more similar on both sample dates to the glacier water samples than to the rainwater samples. This is not surprising as the groundwater was sampled at locations close to the proglacial stream.

\section{Isotopic composition in tree ring cellulose}

Before interpreting these data, it is important to note the large difference in values between the isotopic composition of the water sources (Table 1) and those of tree cellulose (Table 2). No studies have yet characterised and quantified the exact fractionation of $\mathrm{H}$ isotopes during the assimilation of water and formation of cellulose in the trees used in this study. Moreover, while for any one species of plant, the most important control on the isotopic composition of the cellulose is indeed the local ground/soil water isotopic composition, each species will fractionate to a different degree the root zone water used and hence the transfer function to the isotopic composition of the cellulose cannot be generalised for all plants (e.g., Valentini et al. 1993, McCarroll and Loader 2004).

If the sole source of water for the trees was precipitation, and the isotopic composition was solely determined by the water source, then we would expect a clear negative relation between altitude and cellulose $\delta^{2} \mathrm{H}$ values (e.g., McCarroll and Loader 2004, Nolin et al. 2010). The correlation between altitude and $\delta^{2} \mathrm{H}$ for the data in Table 2 is not significant $(r=0.394, p>0.05)$. However, there is a signal related to the effects of different zones. The $\mathrm{Z} 1 \delta^{2} \mathrm{H}$ series has an average isotopic composition of $-154.5 \pm 5.1 \%$ o, which is the lowest 
of the three studied sites. Compared with Table 1, this suggests that the waters taken up by the trees in this zone are likely dominated by meltwater, which is consistent with the statement made earlier: the sampled trees, selected because of their evident proximity to glacial meltwater, record the origin of the water they are fed with. The Z3 $\delta^{2} \mathrm{H}$ series, for the distal sampled trees, shows the highest average $\delta^{2} \mathrm{H}$ values of the three sites $(-132.0$ $\pm 3.7 \%$ ). These sites are farthest from the proglacial stream and are more likely to be taking water from meteoric precipitation. The $\mathrm{Z2} \delta^{2} \mathrm{H}$ average value is $-149.0 \pm 9.4 \%$, which is consistent with the hypothesis that water at this site is supplied by meltwater and lesser amounts of local precipitation compared to the Z3 site. This series is also inversely correlated with temperature $(r=-0.84, p<0.05$, Figure 6$)$. In other words, an increase in annual temperature has the effect of a decrease in isotopic values. This is likely due to an increased use of glacial melt-derived water following from enhanced glacier melt during the warmer periods (e.g., Halder et al. 2013). This relationship becomes clear when the isotopic composition of the three zones is plotted against mean temperature values (Figure 6). At lower temperatures, Z2 values are closer to the Z3 series values. But with increasing temperature, the $\mathrm{Z} 2$ series gradually gets closer to the $\mathrm{Z} 1$ values.

This shift is also evident from Figure 7, which uses windowed correlation to show the relation between growth rates in the three zones and the respective isotopic composition of the tree cellulose. The Z1 growth rates appear to be inversely correlated with the isotopic composition throughout, which is consistent with the hypothesis that trees in this zone respond to variations in available glacial melt-water. This inverse correlation is stronger during the first two decades of this study. Z3 growth rates are more weakly, but positively, correlated with the isotopic composition. However, it is consistent with the hypothesis that this zone is fed by waters of relatively heavy isotopic composition, most likely precipitation influenced. Z2 growth rates demonstrate an important evolution over time. At the beginning of the study period, the Z2 growth rates are positively correlated with isotopic composition. A shift occurs around 1998-2002 (depending on the window size) when the correlation is reversed and becomes gradually more negative over time. This is consistent with a switch from rainfall influencing the isotopic composition to meltwater sources dominating the isotopic composition.

\section{Discussion}

By using growth rates combined with isotopic composition of tree rings we were able to use the $\delta^{2} \mathrm{H}$ values to identify the water sources used by trees in a proglacial zone in a region subject to climate warming, declining precipitation and glacier recession. The results confirm those of other studies that prove the effectiveness of $\delta^{2} \mathrm{H}$ values in identifying the water sources used in cellulose formation (Guanghui and Sternberg, 1993; Dawson et al., 2002; Keppler and Hamilton, 2008, Cernusak et al., 2016) and that it is possible to detect glacial melt water contributions in tree-ring isotopic compositions (e.g., Leonelli et al. 2014, 2017).

The results demonstrate that the melting of the Olguin glacier may have a direct influence on tree growth, depending on where trees are located within the proglacial margin. The 
growth of trees located in the proglacial stream distal zone (Z3), the zone least likely to have access to glacially-derived water, showed no significant correlation with temperature (Figure 5, Z3). Z3 growth rates were mainly dependent on average rainfall during the growing season. Trees located in the proglacial stream proximal zone (Z1) had growth rates unrelated to precipitation, but correlated with temperature (Figure $5, Z 1$ ) suggesting that temperature was the limiting growth factor for the trees because glacially-derived water was able to reduced dependence on meteoric precipitation. Although here, as in Z3, tree growth shows a slight decrease over the years due to the decrease in precipitation over the last thirty years. The relationship between climatic variables and growth rates in the intermediate zone (Z2) evolved as a function of time. Initially, they were correlated with precipitation, but they become increasingly correlated with temperature as a function of time (Figure 5, Z2). In other words, Z2 trees gradually change from being water-limited as with Z3 to being temperature limited as with Z1. We suggest that this may be due to the accelerated melting of ice, which may increase the amount of melt water available in the fore-field through direct runoff or via groundwater. Trees located in this area are now fed more by melt water and so are less dependent on precipitation variability.

Thus, the primary finding of this research is that with climate warming and drying, tree growth in a glacial fore-field responds as a function of the extent to which trees can compensate for declining precipitation by accessing alternatives to precipitation, and notably glacial meltwater. Trees that have access to melt water (by stream flow or through groundwater) can maintain or increase their growth rates as compared to trees that do not. Vegetation establishment, or in this case the study of tree growth rates, under rapid climate change must take into account both surface and subsurface hydrology and how this is able to compensate for the hydrological stress that can arise if a warming climate is also accompanied by a dryer climate. This finding confirms the importance of other research that has emphasised the importance of soil moisture as a driver of vegetation succession after glacier recession (e.g. Burga et al. 2010; Caccianiga and Andreis 2011; Rydgen et al. 2014; Miller and Lane, 2019). Soil moisture is likely to be of importance for other elements of vegetation succession such as microbial systems (Marteinsdóttir et al., 2010, 2013; Raffl et al., 2006; Robinson et al., 2008; Rydgren et al., 2014; Levy et al., 2015; Schumann et al., 2016).

This study uses a relatively simple distance from the meltwater stream as the surrogate for a changing gradient in access to groundwater. Wider floodplains, or floodplains with different shallow and deep groundwater characteristics (e.g., Robinson et al., 2008; Levy et al., 2015) may have a response with greater spatial heterogeneity. There is certainly evidence that the proglacial stream can be a source of shallow groundwater on a daily basis due to hydrograph rise (e.g. Cooper et al., 2002; Magnusson et al., 2014; Deuerling et al., 2018).

It was not possible to establish the spatial extent of proglacial stream influence in this study, and this points to a need for more studies of groundwater flux in proglacial stream margins. If the proglacial stream is important, then progressive glacier retreat may also lead to longer-term and progressive lowering of water supply (Levy et al., 2015). However, 
stream morphodynamics matter as either river incision or deposition, or lateral river channel shifts will determine the depth and duration of lateral water flux, and hence which zones can access stream water. There is evidence of systematic stream morphodynamic response as glaciers retreat (e.g. incision followed by aggradation; Marren, 2002; Beylich et al 2009; Marren and Toomath, 2014; Roussel et al 2018) but these have yet to be linked to shallow groundwater behaviour. In our case, whilst it seems likely that the growth rates have been influenced by the extent to which glacial melt water is available, we cannot differentiate between proglacial stream driven lateral sources and other fluxes, including those fluxes through proglacial forefield sediments directly from the glacier and the meltout of buried ice. Work is needed to quantify such flow paths and their evolution in response to glacier recession. That said, the identification of the influence of glacial melt water on growth rates explains why, faced with rapid glacier recession, we are not seeing the development of longitudinal chronosequences in successional processes; lateral gradients in successional processes, dominated by the relationship between the proglacial stream and its margins, are becoming more dominant than longitudinal ones.

Longer-term, proglacial marginal zones where climate change also involves reduced precipitation will only benefit from increased glacial melt as long as there is sufficient glacial cover in the basin. As glaciers shrink progressively, and the glacial subsidy associated with warming-driven ice melt comes to an end (Collins, 2008), proglacial runoff may fall (Sorg et al., 2014) there may be a transition back to precipitation limitation of growth rates in intermediate zones and it makes sense to hypothesise that it is the intermediate kind of zone described in this study that will be more sensitive to this effect.

\section{Conclusion}

This paper suggests that using $\delta^{2} \mathrm{H}$ values in tree rings is an effective way to identify the water sources available to trees in a revegetating proglacial environment. It is also shown that an increased water supply can be associated with temperature-driven glacier melting, which may compensate for a decreasing water supply from precipitation and hence influence tree growth. This process most likely reflects the spatial organisation of surface and sub-surface water flow, and hence influences the vegetation cover within the drainage basin. Moreover, this influence is clearly dynamic. Climate change, by influencing hydrological regimes, alters tree growth over time. When studying ecological succession in recently deglaciated terrain, this parameter should therefore be taken into account in the long term. As others have argued (see review in Miller and Lane, 2019), it challenges the classic chronosequence model. Research is now needed to understand the extent to which, and under what conditions, sources and flow paths of groundwater in recently deglaciated terrain are changing in response to climate. Future studies, by conducting research on a larger geographical and temporal scale, could use $\mathrm{H}$ isotope compositions to recreate the hydrological past of an entire catchment basin so allowing understanding of how changing climate is impacting flow paths and ecosystem processes even at sites that have not been instrumented. 


\section{Acknowledgements}

The assistance of Adeline Frossard during data collection is gratefully appreciated. We particularly welcome constructive but critical comments from the Editor Keith Smetten and an anonymous reviewer. The research was funded by the University of Lausanne.

\section{Data availability statement}

Data used in the paper are also published as Supplementary Online Only Material linked to this article

\section{References}

Aniya M. (1988) Glacier Inventory for the Northern Patagonia Icefield, Chile, and Variations 1944/45 to 1985/86. Artic and Alpine Research 20179

Barnett, T.P., Adam, J.C., and Lettenmaier, D.P. (2005) Potential impacts of a warming climate on water availability in snow-dominated regions. Nature 438 303-309

Beylich, A., Laute, K., Liermann, S., Hansen, L., Burki, V., Vatne, G., Fredin, O., Gintz, D. and Berthling, I. (2009) Subrecent sediment dynamics and sediment budget of the braided sandur system at Sandane, Erdalen (Nordfjord, Western Norway) Norsk Geografisk Tidsskrift 63 123-131

Briffa, K.R., Jones. P.D., Schweingruber, F.H., Karlén, W. and Shiyatov, S.G., 1996. Treering variables as proxy-climate indicators: Problems with low-frequency signals. In: Jones PD, Bradley RS, Jouzel J, eds. Climatic Variations and Forcing Mechanisms of the Last 2000 Years. Berlin, Germany: Springer-Verlag, pp 9-41.

Brown, L.E., Milner, A.M., and Hannah, D.M. (2007) Groundwater influence on alpine stream ecosystems. Freshwater Biology 52 878-890.

Brunetti, M., Lentini G., and Maugeri M. (2009) Climate variability and change in the Greater Alpine Region over the last two centuries on multi-variable analysis. International Journal of Climatology 29.

Burga, C.A., Krüsi B., Egli M., Wernli, M., Elsener, S., Ziefle, M., Fischer, T. and Mavris, C. (2010) Plant succession and soil development on the foreland of the Morteratsch glacier (Pontresina, Switzerland): Straight forward or chaotic? Flora - Morphology, Distribution, Functional Ecology of Plants 205 561-576.

Caccianiga, M. and Andreis, C. (2001) Vegetation and environmental factors during primary succession on glacier forelands: some outlines from the Italian Alps. Plant Biosystems 135 295-310.

Cannone, N. (2008) Accelerating Climate Change Impacts on Alpine Glacier Forefield Ecosystems in the European Alps. Ecological Applications 18 637-648.

Casassa, G., Haeberli W., Jones G., Kaser, G., Ribstein, P., Rivera, A. and Schneider, C. (2007) Current status of Andean glaciers. Global and Planetary Change 59 1-9

Cernusak, L., Barbour, M. M., Arndt, S. K., Cheesman, A. W., English, N. B., Feild, T. S., Helliker, B. R., Holloway-Phillips, M. M., Holtum, J. A. M., Kahmen, A., Mclnerney, F. A., Munksgaard, N. C., Simonin, K. A., Song, X., Stuart-Williams, H., West, J. B., and Farquhar, G. D. (2016) Stable isotopes in leaf water of terrestrial plants. Plant, Cell and Environment 39 1087-1102.

Clark, D. and Fritz, P. (editors) (1997) Environmental isotopes in hydrogeology. CRC Press, 343 pages. 
Coaz, J. (1887) Erste Ansiedlung phanerogamer Pflanzen auf vom Gletscher verlassenen Boden. Mitteilungen der Natur. Available at: https://scholar.google.ch/scholar?hl=enandas_sdt=0,5andq=Coaz,+J.,+1887\%3A + Erste+ansiedlung+phanerogame+pflanzen+auf+vom+gletscher+verlassenen+bo den.+Mitteilungen+der+Natur-+forschenden+Gesellschaft+in+Bern,+1886\%3A+312. (accessed 18 June 2018).

Collins, D. (2008) Climatic warming, glacier recession and runoff from Alpine basins after the Little Ice Age maximum Ann Glaciol 48 119-124

Cooper, W.S. (1923) The Recent Ecological History of Glacier Bay Alaska: II. The Present Vegetation Cycle. Ecology 3 223-246.

Cooper, R.J., Wadham, J.L., Tranter, M., Hodgkins, R. and Peters, N.E. (2002) Groundwater hydrochemistry in the active layer of the proglacial zone, Finsterwalderbreen, Svalbard. Journal of Hydrology 269 208-223

Craig, H. (1961) Isotopic variations in meteoric waters. Science 133: 1702-1703.

Criss, R. (1999) Principles of stable isotope distribution. Oxford University Press 264.

Dansgaard, W. (1964) Stable isotopes in precipitation. Tellus 16 411-537.

Dawson T.E., Mambelli, S., Plamboeck, A.H., Templer, P.H. and Tu, K.P., (2002) Stable isotopes in plant ecology. Annual Review of Ecology and Systematics 33 507-59

Deuerling, K.M., Martin, J.B., Martin, E.E. and Scribner, C.A. (2018) Hydrologic exchange and chemical weathering in a proglacial watershed near Kangerlussuaq, west Greenland. Journal of Hydrology 556 220-32

Dyurgerov, M. and Meier, M. (2000) Twentieth century climate change : evidence from small glaciers. PNAS 97 1406-1411.

Gardner, A., Moholdt, G., Cogley G., et al. (2013) A reconciled estimate of glacier contributions to sea level rise: 2003 to 2009. Science 340 852-857.

Garibotti, I., Pissolito, C. and Villalba, R. (2011) Vegetation development on degliaciated rock outcrops from glacier Frias, Argentina. Arctic, Antarctic and Alpine Research 43 35-45.

Glasser, N.F., Harrison, S., Jansson, K.N., Anderson, K. and Cowley, A., 2011. Global sea-level contribution from the Patagonian Icefields since the Little Ice Age maximum. Nature Geoscience, 303-7

Griffin, D. and Anchukaitis, K. (2014) How unusual is the 2012-2014 California drought? Geophysical Research Letters 41, 9017-23

Guanghui, L. and Sternberg, L. (1993) Hydrogen isotopic fractionation by plant roots during water uptake in coastal wetland plants. Chapter 31 in James R. Ehleringer, Anthony E. Hall and Graham D. Farquhar (editors) Stable Isotopes and Plant Carbon-water Relations, Academic Press, 497-510.

Haeberli W., Hoelzle M., Paul, F. and Zemp, M. (2007) Integrated monitoring of mountain glaciers as key indicators of global climate change: the European Alps. Annals of Glaciology 46 150-160.

Haiping, Q., Coplen, T.B., Olack, G.A., and Vennemann, T.W. (2014) Caution on the use of NBS 30 biotite for hydrogen-isotope measurements with on-line high temperature conversion systems. Rapid Communications in Mass Spectrometry 28 1987-1994. 
Halder, J., Decrouy, L., and Vennemann, T.W. (2014) Mixing of Rhône River water in Lake Geneva (Switzerland-France) inferred from stable hydrogen and oxygen isotope profiles. Journal of Hydrology 477 152-164.

Jansson, P., Hock, R. and Schneider ,T. (2003) The concept of glacier storage: a review. Journal of Hydrology 281 116-129.

Keppler, D. and Hamilton, J.T. (2008) Tracing the geographical origin of early potato tubers using stable hydrogen isotope ratios of methoxyl groups. Isotopes Environ Health Studies 44 337-47.

Leonelli, G., Battipaglia, G., Cherubini, P., Saurer, M., Siegwolf, R., Maugeri, M., Stenni, B. , Fusco, S., Maggi, V. and Pelfini, M., (2017) Larix decidua d180 tree-ring cellulose mainly reflects the isotopic signature of winter snow in a high-altitude glacial valley of the European Alps. Science of the Total Environment, 579, 230237.

Leonelli, G., Pelfini, M., Battipaglia, G., Saurer, M. Siegwolf, R.T.W. and Cherubini, P. (2014) First detection of glacial meltwater signature in tree-ring d180: Reconstructing past major glacier runoff events at Lago Verde (Miage Glacier, Italy). Boreas 43, 600-607.

Leuenberger, M. (1998) Stable isotopes in tree rings as climate and stress indicators. Verlag der Fachvereine Hochschulverlag AG, Zürich, 202 pages

Levy, A,, Robinson, Z., Krause, S., Waller, R. and Weatherill, J. (2015) Long-term variability of proglacial groundwater-fed hydrological systems in an area of glacier retreat, Skeiðarársandur, Iceland. Earth Surface Processes and Landforms 40 981-994.

Lynch, C.M., Barr, I.D., Mullan, D. and Ruffell, A. (2016) Rapid glacial retreat on the Kamchatka Peninsula during the early 21st century. The Cryosphere 101809 1821.

Magnusson, J., Kobierska, F. , Huxol, S. , Hayashi, M. , Jonas, T. and Kirchner, J. W. (2014), Melt water driven stream and groundwater stage fluctuations on a glacier forefield (Dammagletscher, Switzerland). Hydrological Processes 28 823-836

Marren, P.M. and Toomath, S.C. (2014) Channel pattern of proglacial rivers: Topographic forcing due to glacier retreat Earth Surface Processes and Landforms 39 943-51

Marren, P.M. (2002) Glacier margin fluctuations, Skaftafellsjökull, Iceland: Implications for sandur evolution Boreas 31 75-81

Marteinsdóttir, B., Svavarsdóttir, K., and Thórhallsdóttir, T.E. (2010) Development of vegetation patterns in early primary succession. Journal of Vegetation Science 21 531-540.

Marteinsdóttir, B., Thórhallsdóttir, T.E. and Svavarsdóttir. K. (2013) An experimental test of the relationship between small scale topography and seedling establishment in primary succession. Plant Ecology 214 1007-1015.

Matthews J (1992) The Ecology of Recently-Deglaciated Terrain, Cambidge University Press, Cambridge

McCarroll, D. and Loader, N.J. (2004). Stable isotopes in tree rings. Quaternary Science Reviews 23 771-801.

McCarroll, D. and Rijsdijk, K. (2003) Deformation styles as a key for interpreting glacial depositional environments. Journal of Quaternary Science 18 473-89 
660

661

662

663

664

665

666

667

668

669

670

671

672

673

674

675

676

677

678

679

680

681

682

683

684

685

686

687

688

689

690

691

692

693

694

695

696

697

698

699

700

701

702

703

704

Meehl G., Washington, W. and Collins, W. (2005) How much more global warming and sea level rise? Science 307 1769-1772.

Miller, H.R. and Lane, S.N. (2019) Biogeomorphic feedbacks and the ecosystem engineering of recently-deglaciated terrain. Forthcoming in Progress in Physical Geography

Otte, I., Detsch, F., Gütlein, A., Scholl, M, Kiese, R., Appelhans, T. and Nauss, T. (2017) Seasonality of stable isotope composition of atmospheric water input at the southern slopes of Mt. Kilimanjaro, Tanzania. Hydrological Processes 31 39323947

Pellicciotti F., Brock B., Strasser U. and Burlando, P. (2005) An enhanced temperatureindex glacier melt model including the shortwave radiation balance: development and testing for Haut Glacier d'Arolla, Switzerland. Journal of Glaciology 51 573587.

Perez, T., Mattar, C. and Fuster, R. (2018) Decrease in snow cover over the Aysen River catchment in Patagonia, Chile. Water 10619.

Raffl, C., Mallaun, M., Mayer, R. and Erschbamer, B. (2006) Vegetation Succession Pattern and Diversity Changes in a Glacier Valley, Central Alps, Austria. Arctic, Antarctic, and Alpine Research 38 421-428.

Rasmussen, L., Conway, H. and Raymond, C. (2007) Influence of upper air conditions on the Patagonia icefields. Global and Planetary Change 59 203-216.

Rebetez, M. and Reinhard, M. (2007) Monthly air temperature trends in Switzerland 19012000 and 1975-2004. Theoretical and Applied Climatology 91 27-34.

Robinson, Z.P., Fairchild, I.J., and Russell, A.J. (2008) Hydrogeological implications of glacial landscape evolution at Skeiðarársandur, SE Iceland. Geomorphology 97 218-236.

Rosenblüth, B., Casassa, G., and Fuenzalida, H. (1995) Recent climatic changes in western Patagonia. Bulletin of Glacier Research 13 127-132.

Roussel, E., Marren, P.M., Cossart, E., Toumazet, J.P., Chenet, M., Grancher, D. and Jomelli, V. (2018) Incision and aggradation in proglacial rivers: Post-Little Ice Age long-profile adjustments of Southern Iceland outwash plains Land Degradation and Development 29 3753-71

Rydgren, K., Halvorsen, R., Töpper, J.P., and Njos, J.M. (2014) Glacier foreland succession and the fading effect of terrain age. Journal of Vegetation Science 25 1367-1380.

Schumann, K., Gewolf, S., and Tackenberg, O. (2016) Factors affecting primary succession of glacier foreland vegetation in the European Alps. Alpine Botany 126 $105-117$.

Shortle, W. (2012) Wood decay in living and dead trees: A pictorial overview. USDA, Report NRS-97.

Siegenthaler, U. and Oeschger, H. (1980) Correlation of 180 in precipitation with tempertaure and altitude. Nature 285 314-317.

Sorg, A., Huss, M., Rohrer, M. and Stoffel, M., 2014 The days of plenty might soon be over in glacierized Central Asian catchments. Environmental Research Letters, 9, 104018

Speer, J. (2012) The fundamentals of Tree-Ring research. University of Arizona Press. 
Sullivan P., Pattison, R.R., Brownlee, A.H., Cahoon, S.M.P. and Hollingsworth, T.N., (2016) Effect of tree-ring detrending method on apparent growth trends of black and white spruce in interior Alaska. Environmental Research Letters 11114007.

Tognetti, R., Lombardi. F., Lasserre, B., Cherubini, P. and Marchetti, M. (2014) Tree-Ring Stable Isotopes Reveal Twentieth-Century Increases in Water-Use Efficiency of Fagus sylvatica and Nothofagus spp. in Italian and Chilean Mountains. PLoS ONE, 9, e113136.

Valentini, R., Anfodillo, T. and Ehleringer, J.R. (1993) Water sources and carbon isotope composition $(\bar{\delta} 13 \mathrm{C})$ of selected tree species of the Italian Alps. Canadian Journal of Forest Research 24 1575-1578.

Wietrzyk, P., Wegrzyn, M., and Lisowska, M. (2016) Vegetation diversity and selected abiotic factors influencing the primary succession process on the foreland of Gasbreen, Svalbard. Polish Polar Research 37 493-509. 
722 Table 1. Hydrogen isotopic composition of different water sources collected in the Olguin 723 glacier watershed.

724

\section{Water source and distance above} sea level

Rain water $(700 \mathrm{~m})$

Rain water $(700 \mathrm{~m})$

Rain water $(50 \mathrm{~m})$

Glacier ice (sampled at the tongue)

Glacial stream/torrent $(60 \mathrm{~m})$

Glacial stream/torrent $(600 \mathrm{~m})$

Glacial stream/torrent $(700 \mathrm{~m})$

Glacial stream/torrent $(750 \mathrm{~m})$

Glacial stream/torrent $(850 \mathrm{~m})$

Grey lake water $(50 \mathrm{~m})$

Groundwater (300 m)

Groundwater (300 m)

\section{Sampling date}

December 16, 2016

January 13, 2017

December 16, 2016

December 12, 2016

December 15, 2017

December 17, 2016

December 15, 2016

December 15, 2016

December 12, 2016

December 9, 2016

January 13, 2017

February 15, 2017 $\delta^{2} H$

VSMOW

$-84.1$

$-71.6$

$-96.9$

$-101.1$

$-105.2$

$-102.2$

$-106.9$

$-107.7$

$-109.0$

$-96.8$

$-102.9$

$-103.8$
726

727

728

729

730

Table 2. Altitude of sampled tree cellulose and their mean $\delta^{2} \mathrm{H}$ composition. Zonal means are based on only those samples where mean $\delta^{2} \mathrm{H}$ composition data are presented.

\begin{tabular}{|c|c|c|}
\hline Sample & $\begin{array}{l}\text { Mean } \delta^{2} H(\% o) \\
\text { VSMOW }\end{array}$ & Elevation (m) \\
\hline Z1A & - & \\
\hline Z1B & $-155.7 \pm 6.3$ & 797 \\
\hline Z1C & $-155.7 \pm 6.8$ & 594 \\
\hline Z1D & $-153.5 \pm 7.5$ & 552 \\
\hline Z1E & - & 556 \\
\hline Z1F & - & 545 \\
\hline Z1G & - & 382 \\
\hline Z1H & $-153.0 \pm 17.9$ & 310 \\
\hline Z1I & - & 312 \\
\hline Z1J & - & 356 \\
\hline Z1 mean & $-154.5 \pm 5.1$ & 563 \\
\hline Z2A & $-146.7 \pm 9.9$ & 586 \\
\hline Z2B & - & 512 \\
\hline Z2C & $-149.6 \pm 14.2$ & 448 \\
\hline Z2D & $-150.8 \pm 25.2$ & 350 \\
\hline $\mathrm{Z2E}$ & $-148.7 \pm 4.9$ & 474 \\
\hline Z2F & - & 567 \\
\hline Z2G & - & 386 \\
\hline Z2H & - & 432 \\
\hline Z2I & - & 245 \\
\hline Z2J & - & 266 \\
\hline $\mathrm{Z2}$ mean & $-149.0 \pm 9.4$ & 465 \\
\hline Z3A & $-126.8 \pm 4.8$ & 399 \\
\hline Z3B & - & 412 \\
\hline Z3C & - & 454 \\
\hline Z3D & - & 378 \\
\hline Z3E & $-134.5 \pm 12.5$ & 435 \\
\hline Z3F & - & 316 \\
\hline Z3G & $-133.8 \pm 6.3$ & 465 \\
\hline
\end{tabular}


Z3H

Z3I

Z3J

$\mathrm{Z3}$ mean
$-133.7 \pm 5.8$

-

731

732
448

348

372

437 


\section{Figure Captions}

Figure 1. Study area location in Chile (inset) and the glacier Olguin. Image sources modified composite from ArcGIS World Imagery, Landsat 7, 2017, and Google Maps, NASA, 2018.

Figure 2. Geomorphological schema of the study area and location of sampled trees. Olguin glacier is located at the top of the map. On its left side is an unnamed minor glacier. The Olguin glacial stream flows into Lake Grey located on the bottom left. Tree elevations are given in Table 2.

Figure 3. Annual growth rates; mean (red line); median (blue-green interface), interquartile range (solid bars) and range (whiskers); for Z1 (3a), Z2 (3b) and Z3 (3c) through time.

Figure 4. Plots of annual growth rate against temperature (4a) and precipitation (4b). Marker symbology is the same as in Figure 2.

Figure 5. Windowed correlation (Pearson) analysis for Z1, Z2 and Z3 growth rates and time-series applied for precipitation (column 1) and temperature (column 2). For each combination, a coloured plot indicates the strength of correlation with varying window size along the growth rates.

Figure 6. $\mathrm{Z} 1, \mathrm{Z2}$ and $\mathrm{Z} 3 \delta^{2} \mathrm{H}$ values in relation to temperature. With increasing temperatures, the $Z 3$ values decrease to approach those of $Z 1$.

Figure 7. Windowed correlation (Pearson) analysis for Zones 1 to 3 growth rates against mean isotopic composition. For each combination, the coloured plot indicated the strength of the correlation with varying window size along the growth rates. 


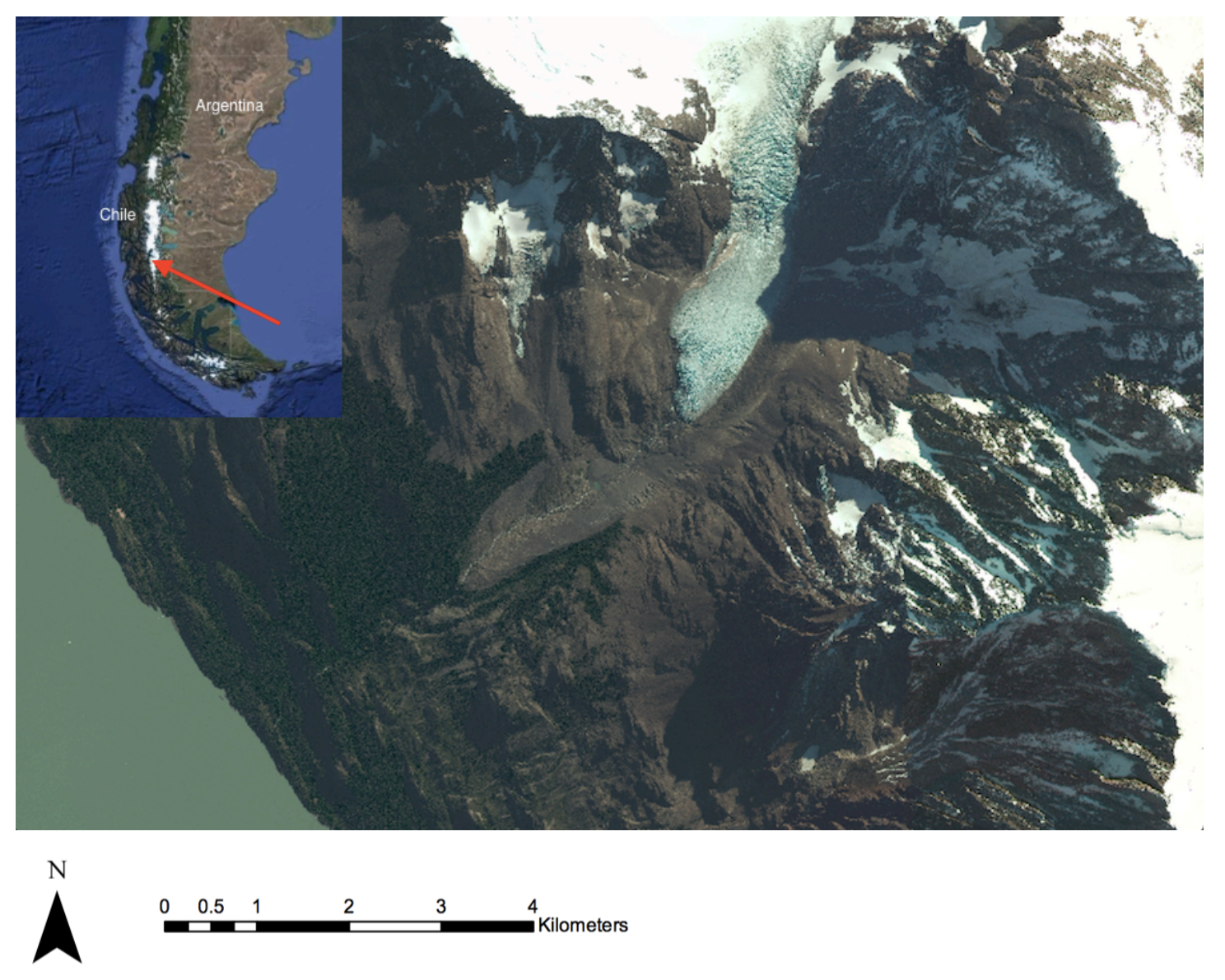




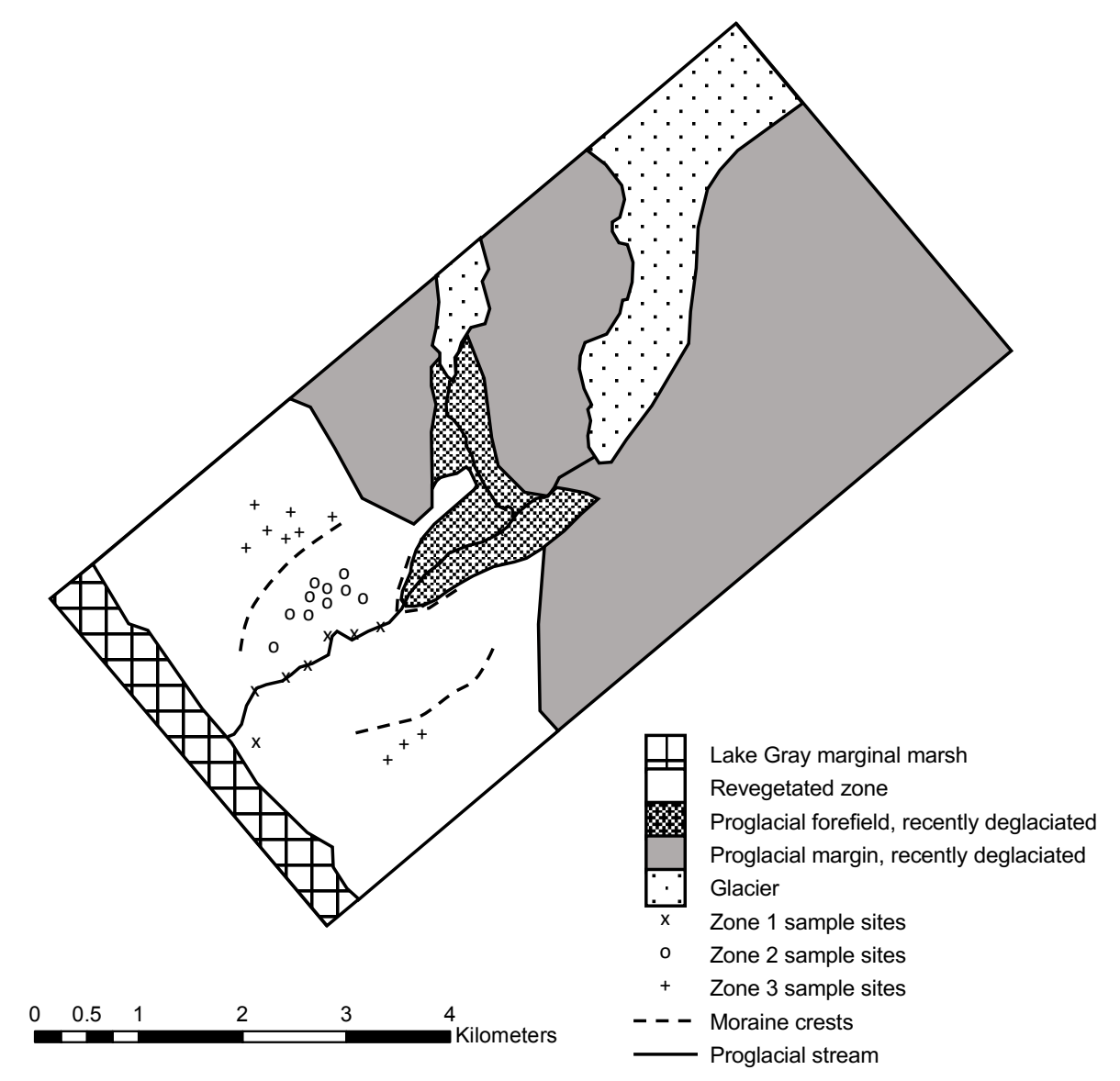

$\bigwedge^{\mathrm{N}}$ Marceline Vuaridel, 2018 


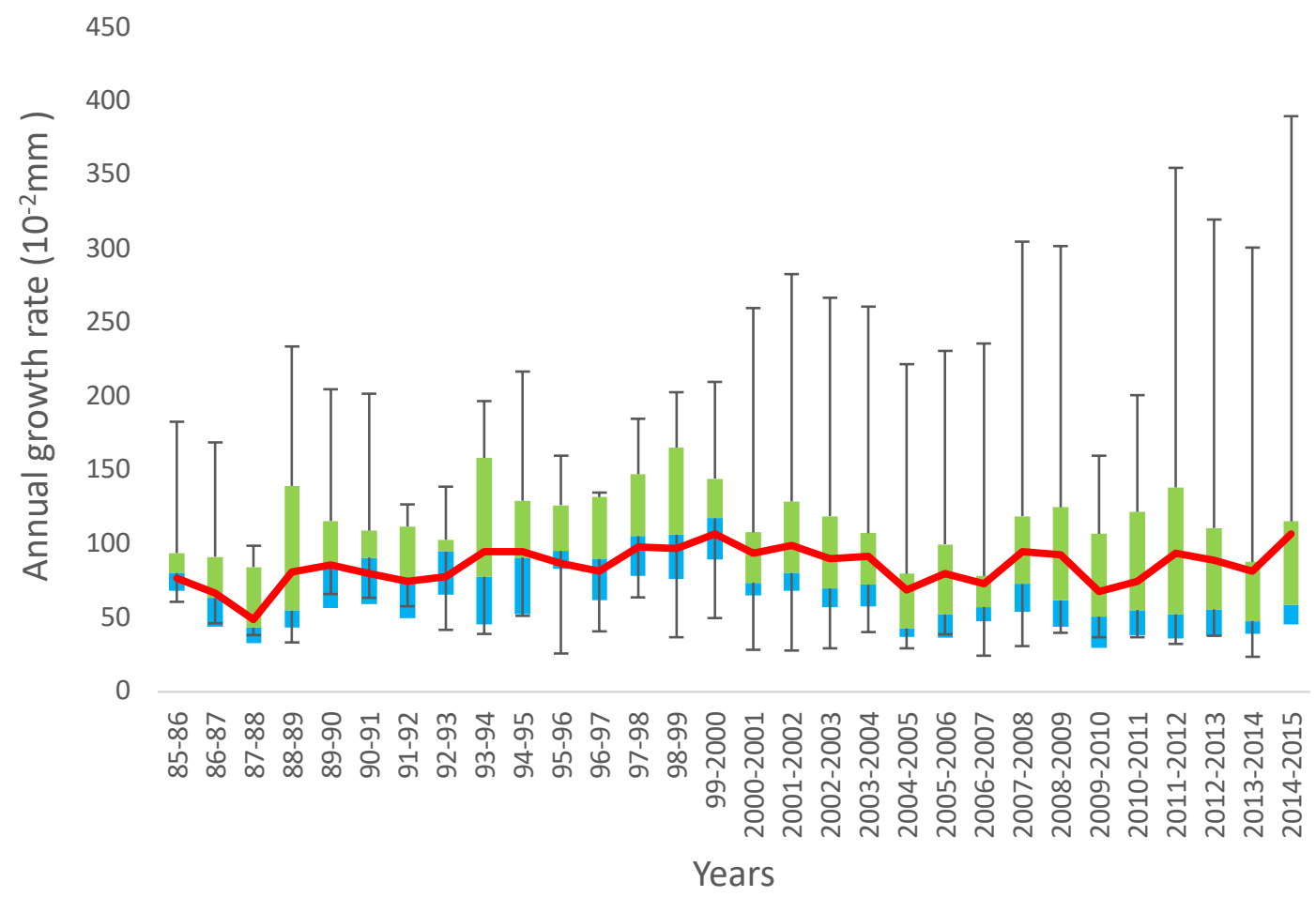




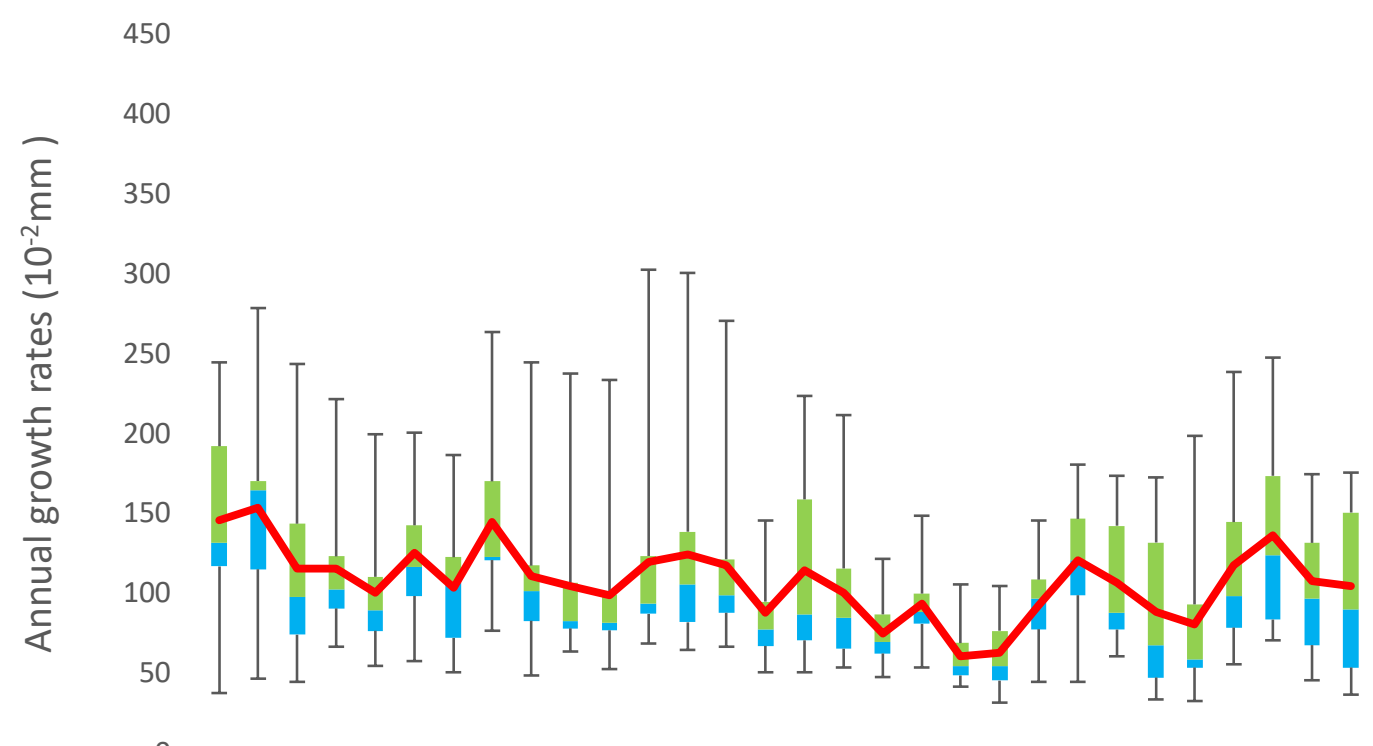

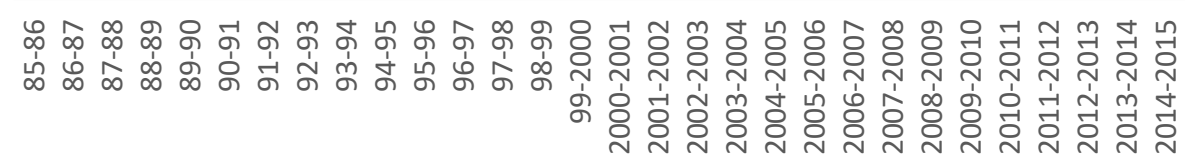
Years 


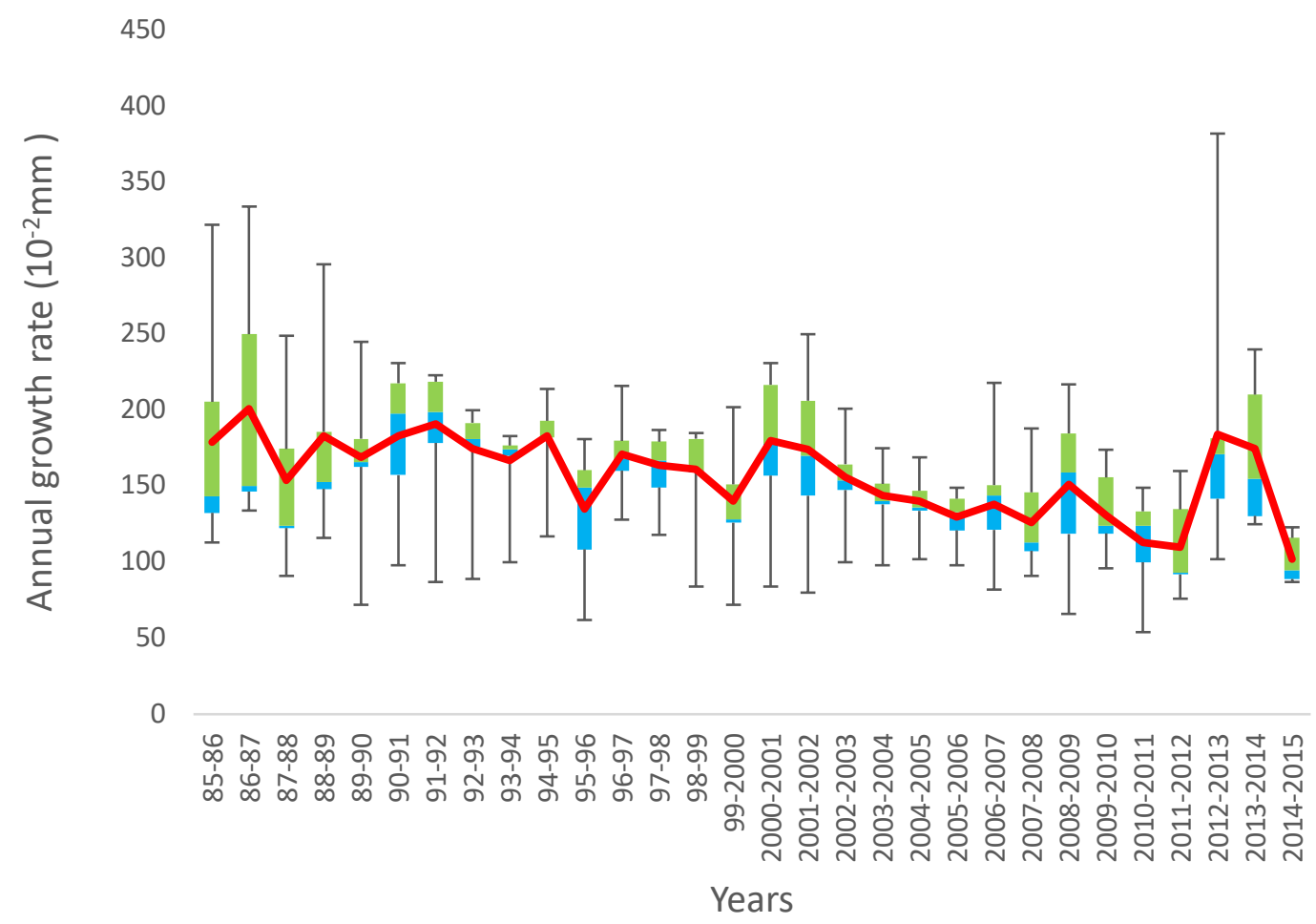




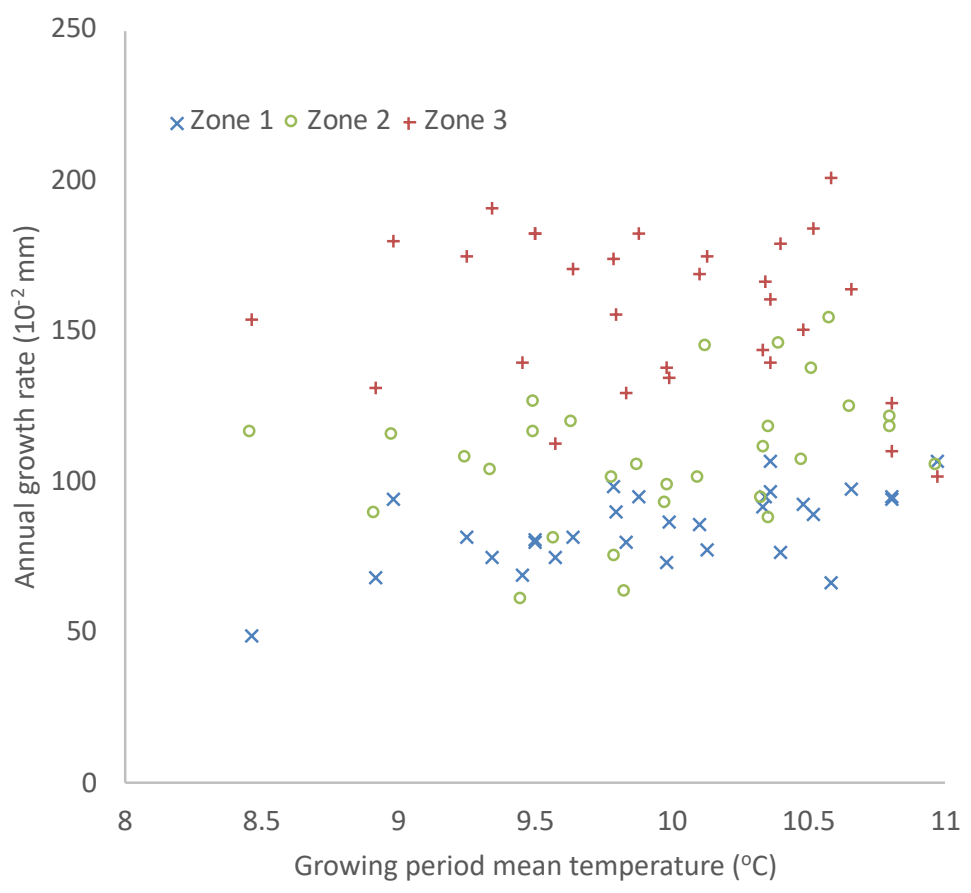




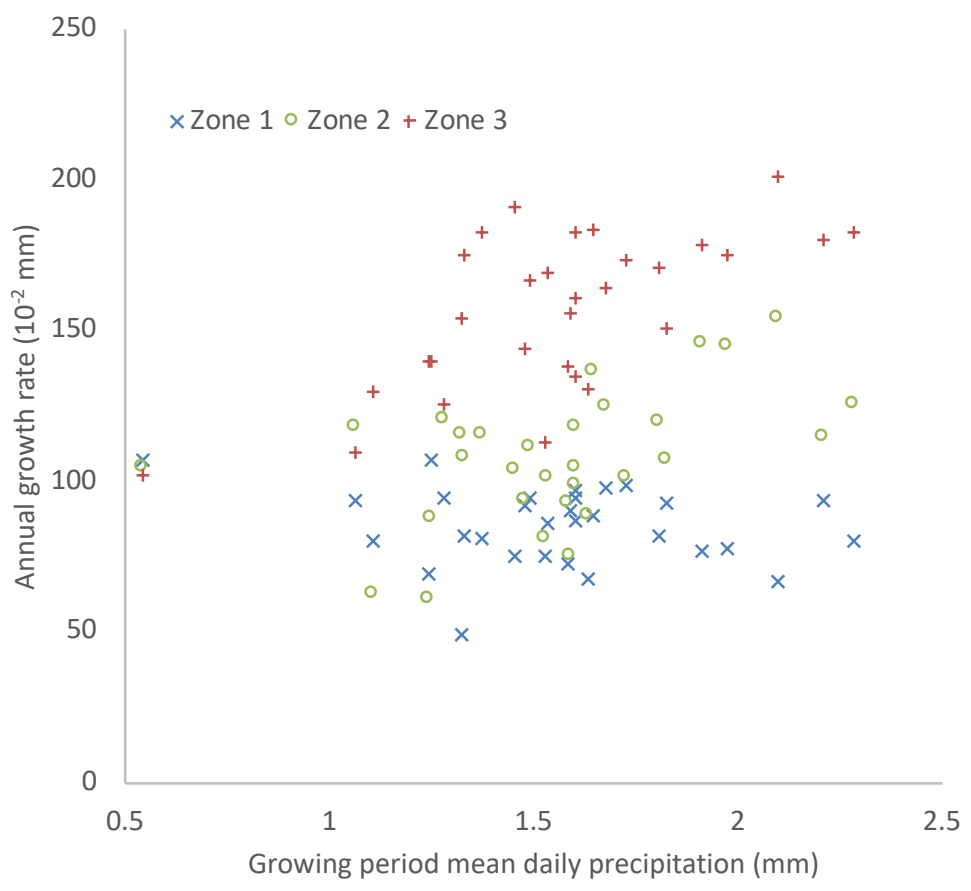


Precipitation
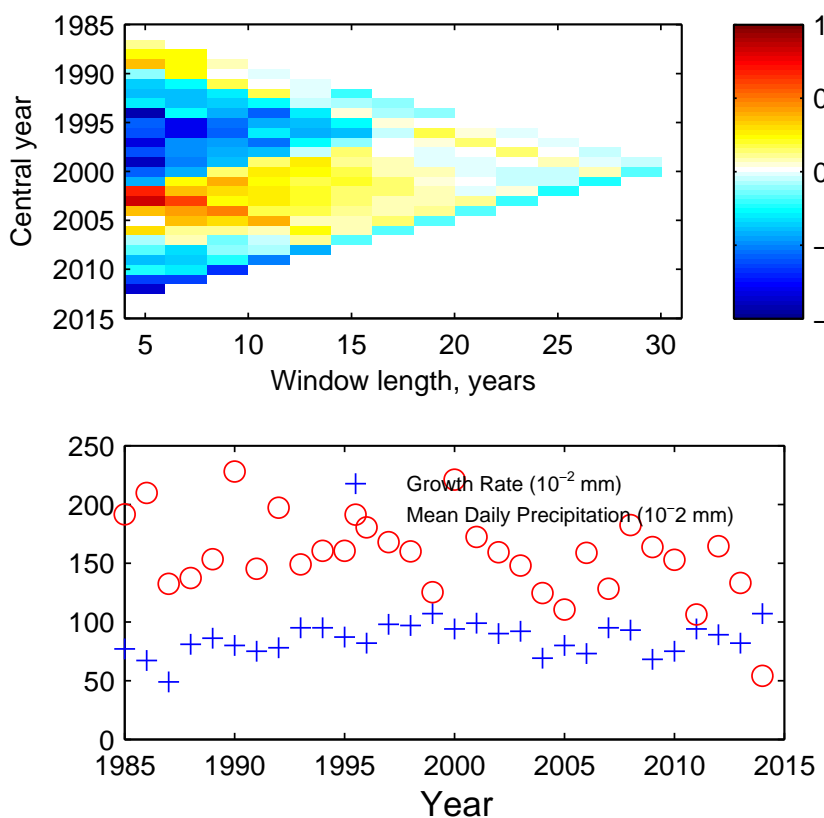

Z2
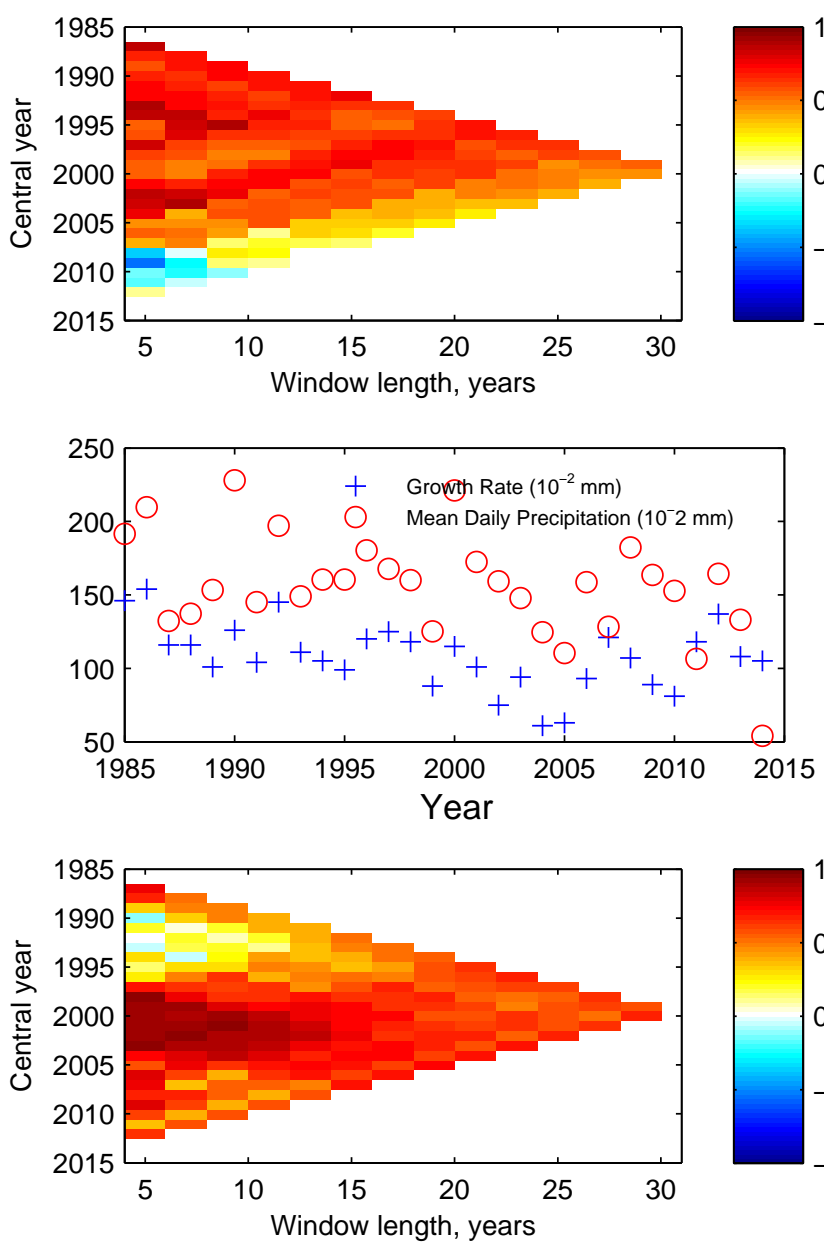

Z3
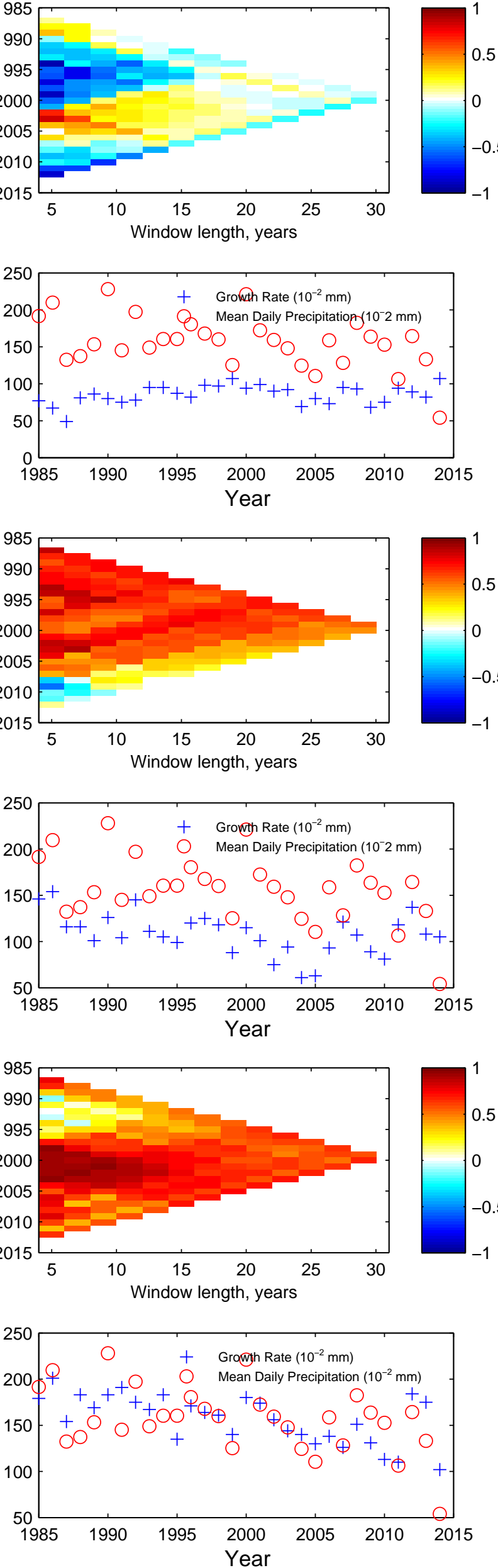

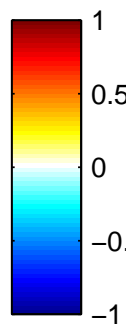

Temperature
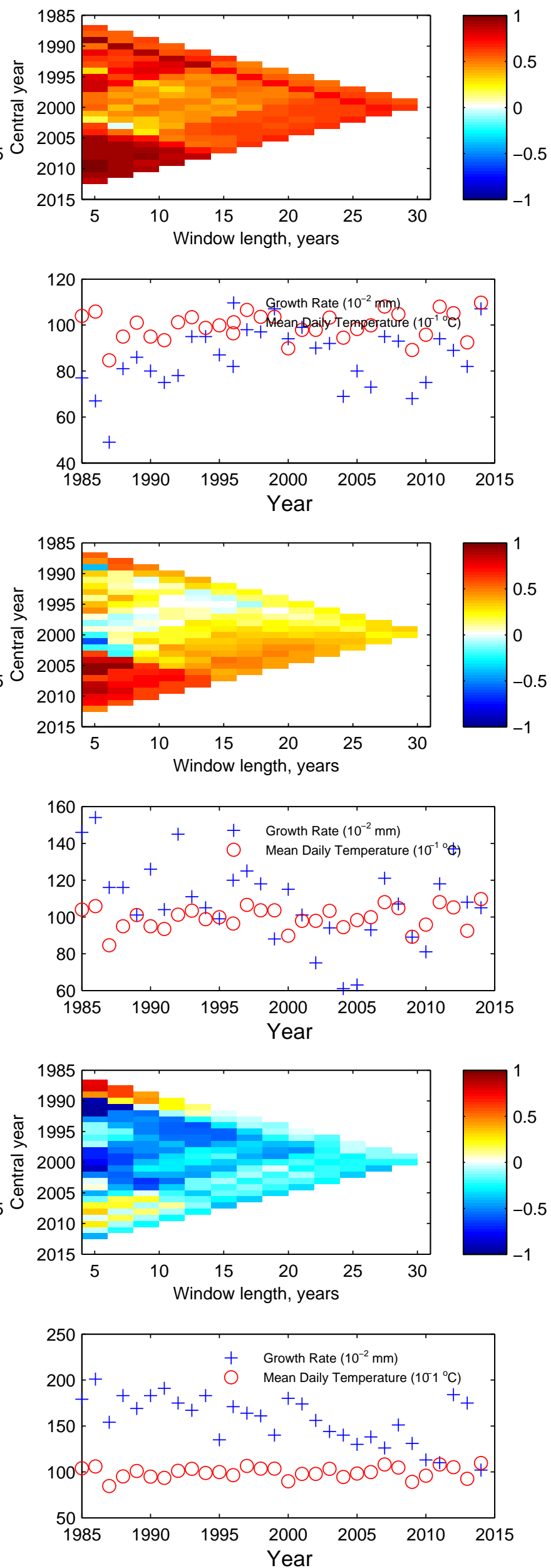


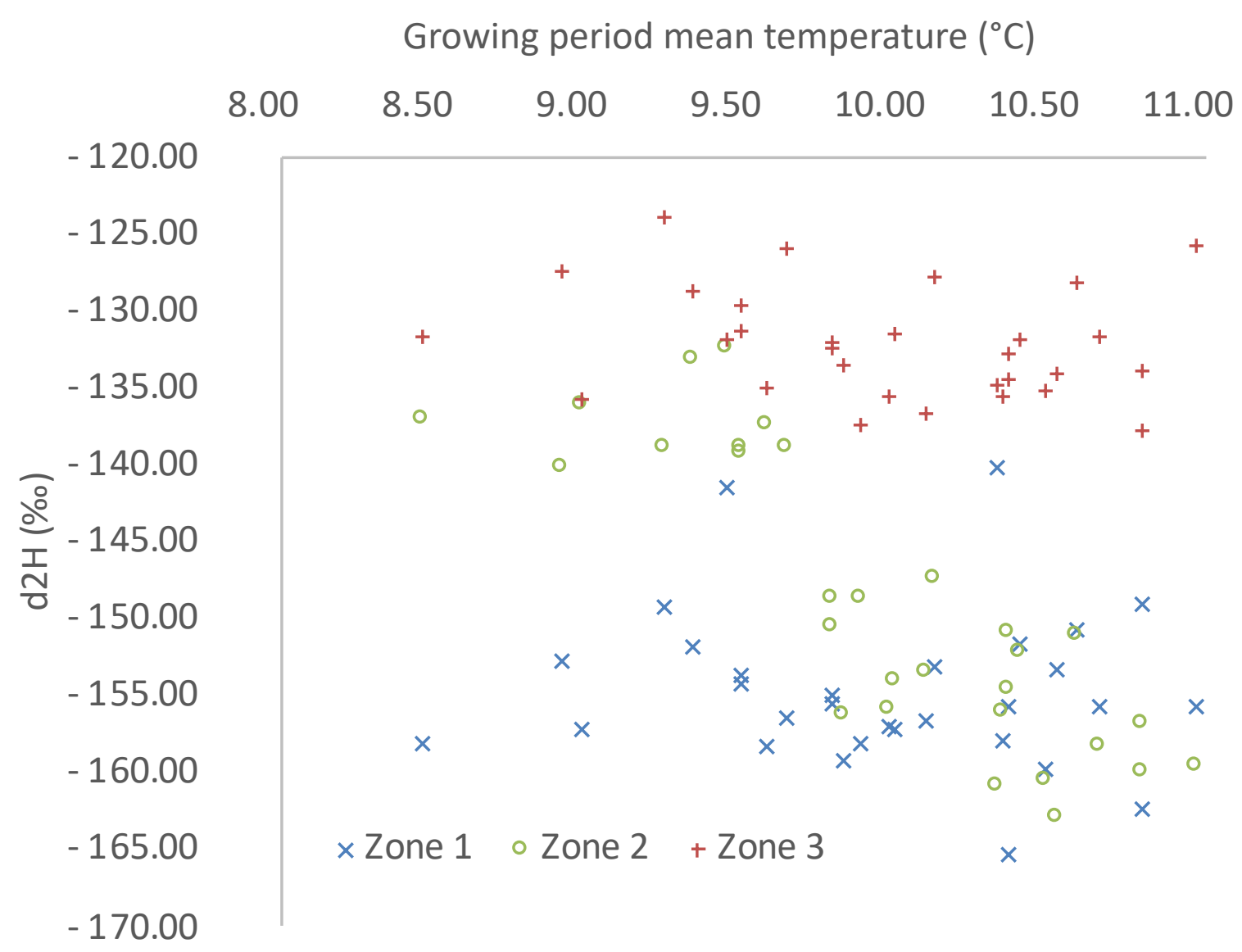




\section{Windowed correlation}
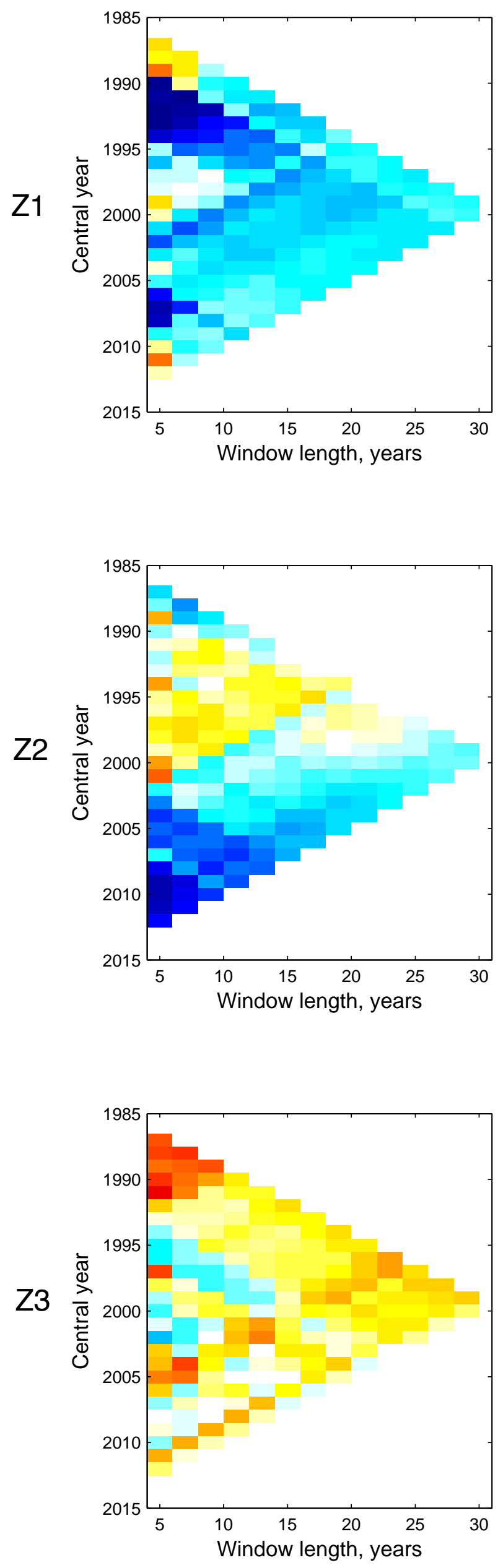

\section{Time-series}
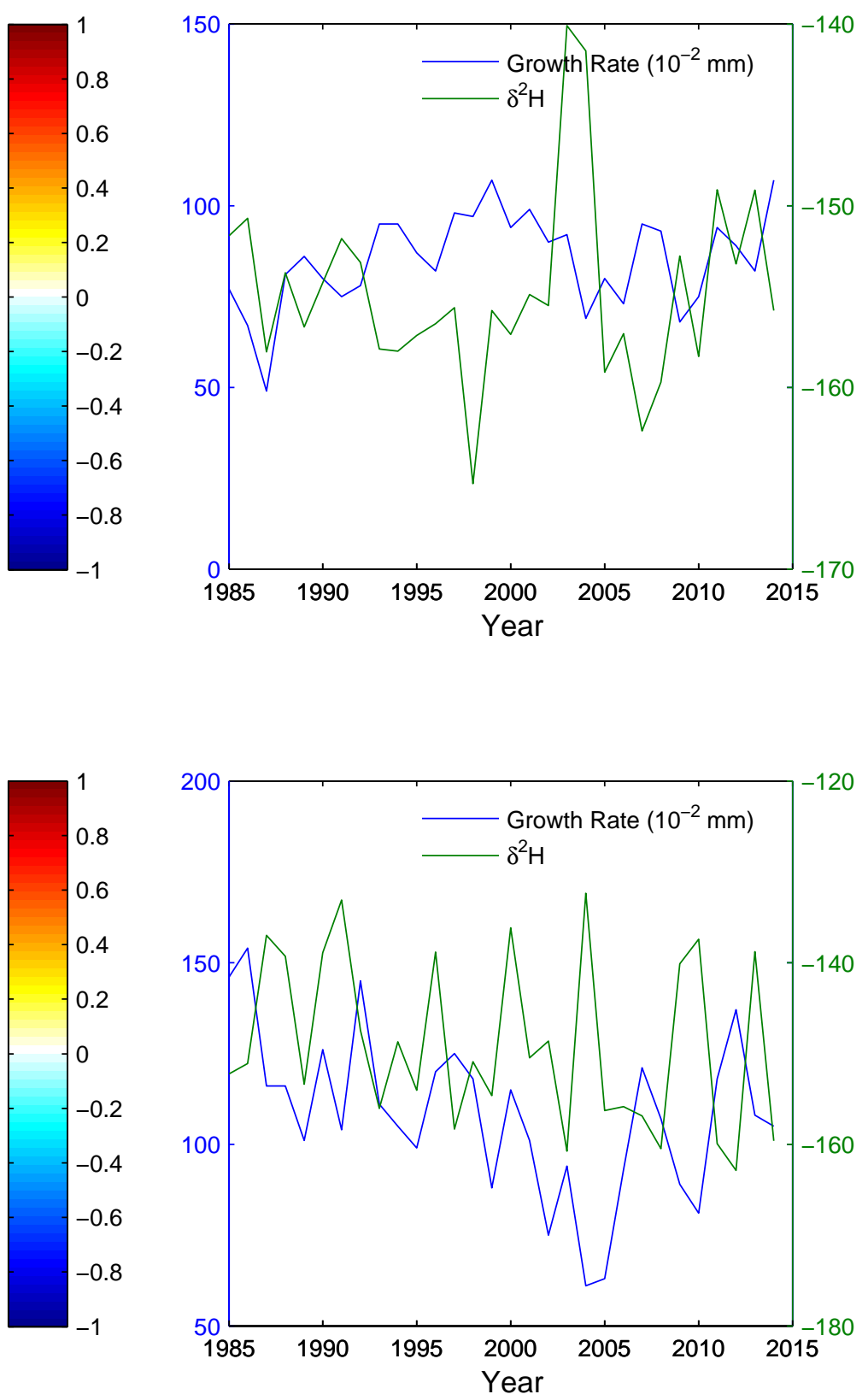
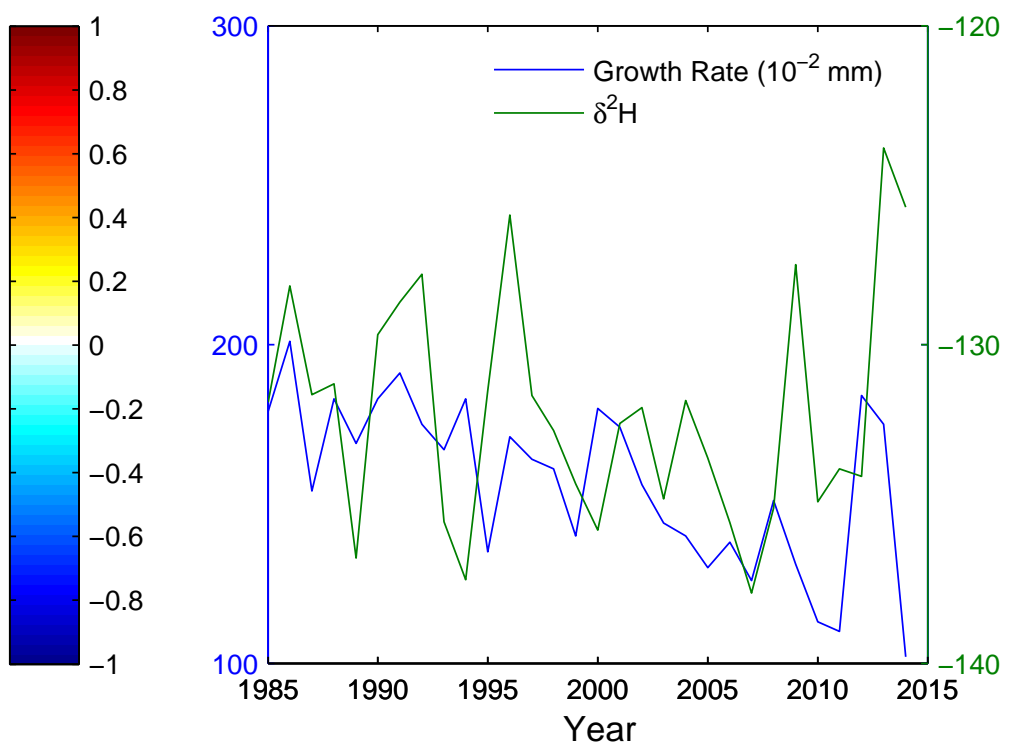